\title{
Проблемы фальсификации молочной продукции и их влияние на рынок молока и состояние молочной отрасли
}

\author{
Жилинкова К.Б. \\ Курская государственная сельскохозяйственная академия имени И.И. Иванова \\ Россия, 305021, г. Курск, ул. Карла Маркса, д. 70 \\ E-mail: fantasy_sky__@mail.ru
}

\begin{abstract}
Аннотация. Важную роль в обеспечении населения качественными продуктами питания и продовольственной безопасности страны играет молочная отрасль, состояние которой в значительной степени определяется эффективностью рыночных и государственных механизмов регулирования. Одной из острых проблем, в значительной мере вызванной неэффективностью нормативных механизмов регулирования и мешающих развитию молочной отрасли, является масштабное использование в перерабатывающей и пищевой промышленности заменителей молочного жира, различных пищевых добавок и компонентов, что ведет к фальсификации молочной продукции. В отечественной экономической литературе данной проблеме уделяется недостаточно внимания, существуют очевидные пробелы в методологии исследования и методиках оценки данного явления, что приводит к значительным разночтениям, неправильным выводам и выработке неэффективных управленческих решений. Цель данной работы состояла в анализе проблемы фальсификации молочной продукции и совершенствовании методологии ее исследования. Исследование проводилось на материалах официальной статистики с использованием аналитических материалов органов государственного управления, нормативной и научной литературы. В результате исследования было выявлено негативное влияние фальсификации молочной продукции на рынок молока и состояние молочной отрасли. По оценкам автора из-за фальсификации молочное скотоводство недосчитывает до 2 и более млн дойных коров, так как натуральное молоко заменяется суррогатами. При этом фальсифицированная продукция оказывает отрицательное влияние не только на экономику молочной отрасли, но и на здоровье граждан. В статье систематизированы способы, виды и методы фальсификации молока и молочной продукции, составлена наглядная схема влияния фальсифицированной молочной продукции на рынок молока и состояние молочной отрасли. Предложен методический подход к оценке уровня фальсификации молочной продукции на основе сопоставления данных о направлении в переработку молока-сырья и выработки готовой молочной продукции. Полученные результаты могут быть использованы в практической деятельности органов государственной власти для выработки более обоснованных решений по нормативному регулированию рынка молока и молочной продукции.
\end{abstract}

Ключевые слова: рынок, конкуренция, заменители, фальсификация, регулирование.

Для цитирования: Жилинкова К.Б. 2021. Проблемы фальсификации молочной продукции и их влияние на рынок молока и состояние молочной отрасли. Экономика. Информатика. 48(4): 697-706. DOI: 10.52575/2687-0932-2021-48-4-697-706.

\section{The impact of counterfeit dairy products and surrogates on the milk market and the state of the dairy industry}

\author{
Ksenia B. Zhilinkova \\ Kursk State Agricultural Academy named after I.I. Ivanov \\ 70 Karl Marx St., Kursk, 305021, Russia \\ E-mail: fantasy_sky__@mail.ru
}

Abstract. An important role in providing the population with high-quality food and food security of the
country is played by the dairy industry, the state of which is largely determined by the effectiveness of 
market and government regulatory mechanisms. One of the acute problems, largely caused by the ineffectiveness of regulatory mechanisms of regulation and hindering the development of the dairy industry, is the large-scale use of milk fat substitutes, various food additives and components in the processing and food industries, which leads to falsification of dairy products. In the domestic economic literature, not enough attention is paid to this problem, there are obvious gaps in the research methodology and methods for assessing this phenomenon, which leads to significant discrepancies, incorrect conclusions and the development of ineffective management decisions. The purpose of this work was to analyze the problem of falsification of dairy products and improve the methodology of its research. The research was carried out on the materials of official statistics with the use of analytical materials of government bodies, regulatory and scientific literature. The study revealed the negative impact of counterfeiting dairy products on the milk market and the state of the dairy industry. According to the author's estimates, due to falsification, dairy cattle breeding lacks up to 2 million or more dairy cows, since natural milk is replaced by surrogates. At the same time, counterfeit products have a negative impact not only on the economy of the dairy industry, but also on the health of citizens. The article systematizes the ways, types and methods of falsification of milk and dairy products, compiled a visual diagram of the influence of falsified dairy products on the milk market and the state of the dairy industry. A methodological approach to assessing the level of falsification of dairy products is proposed based on a comparison of data on the direction of raw milk processing and the production of finished dairy products. The results obtained can be used in the practical activities of state authorities to develop more substantiated decisions on the regulatory regulation of the milk and dairy products market.

Key words: market, competition, substitutes, falsification, regulation.

For citation: Zhilinkova K.B. 2021. Problems of counterfeiting dairy products and their impact on the milk market and the state of the dairy industry. Economics. Information technologies. 48(4): 697-706 (in Russian). DOI: 10.52575/2687-0932-2021-48-4-697-706.

\section{Введение}

Молоко занимает важное место в рационе большинства россиян, а молочные продукты (масло сливочное, кефир, творог и др.) относят к социально значимым продовольственным товарам. Согласно данным специалистов [Управление Федеральной службы по надзору в сфере защиты прав потребителей и благополучия человека по республики Алтай], организм взрослого человека должен ежедневно получать 1200 мг кальция, основным же его источником является молоко и продукты его переработки. Молочные продукты содержат витамины А и В, которые помогают при транспортировке кальция в клетки. Само молоко используется для профилактики остеопороза, гипертонии и инфаркта миокарда. Медицинская норма потребления молочных продуктов на 1 человека в год - 392 кг в пересчете на молоко (то есть ежедневно не менее 1 л).

За последние 2-3 года в нашей стране производство молока в хозяйствах всех категорий увеличилось на 1 млн тонн или на 3,2\% и достигло 32,2 млн тонн в 2020 г. [Министерство сельского хозяйства Российской Федерации]. Расширился ассортимент молочной продукции, данная группа товаров пользуется стабильным растущим спросом. При таких обстоятельствах у недобросовестных производителей появляется желание сократить затраты (сырье, технология), подделать и увеличить объемы молока и молочной продукции.

\section{Объекты и методы исследования}

В процессе работы использовались монографический, экономико-статистический, расчетно-конструктивный методы, модель пяти конкурентных сил М. Портера.

Объект исследования - рынок молока и молочной продукции. На молоко и молочную продукцию распространяются требования ГОСТов, ТУ и технического регламента Таможенного союза ТР ТС 033/2013 «О безопасности молока и молочной продукции».

Основные требования к молоку выдвигаются следующие: 
- питьевое молоко должно быть изготовлено из цельного нормализованного и обезжиренного молока, с соблюдением гигиенических требований;

- на этикетке должна присутствовать надпись «Состав» и перечень входящих в него компонентов, а также масса нетто или объем, жирность, дата изготовления и срок годности;

- внешне представлять собой непрозрачную однородную, нетягучую, слегка вязкую, без хлопьев белка и сбившихся комочков жира жидкость. Если массовая доля жира более 4,7 \%, допускается незначительный отстой жира, исчезающий при перемешивании;

- без посторонних привкусов и запахов;

- белый цвет. Допускается с синеватым оттенком для обезжиренного молока, со светло-кремовым оттенком для стерилизованного молока, с кремовым оттенком для топленого;

- плотность не менее $1024 \kappa г /$;

- массовая доля белка не менее $3,0 \%$;

- кислотность, $20-21^{\circ} \mathrm{T}$;

- массовая доля сухого обезжиренного молочного остатка (COMO) не менее 8,2 \%;

- не допускается фосфатаза или пероксидаза;

- группа чистоты не ниже 1;

- температура продукта при выпуске с предприятия $4 \pm 2{ }^{\circ} \mathrm{C}$.

\section{Результаты и их обсуждение}

Одной из серьезных проблем на рынке молока и продуктов его переработки остается значительный удельный вес фальсифицированной продукции. Фальсификация пищевой продукции - это умышленное изменение качества, состава, свойств, а также предоставление заведомо неполной и недостоверной информации об ее истинных свойствах, качестве, производителе.

Как отмечает Макеева И.А. [Лютых, 2021], фальсификация продукции может быть связана с отсутствием терминологической системы, учитывающей сырьевое происхождение продукции, особенности технологических процессов, методы контроля и т. п. В этих случаях производители не всегда знают, как правильно и однозначно декларировать продукты, которые не попадают в правовое поле государственных регламентов. Но есть преднамеренный фальсификат. Против такого ни один регламент или стандарт не спасает изготовителей фальсификата не интересуют требования нормативных документов.

В широком смысле фальсификация может рассматриваться как действия, направленные на ухудшение потребительских свойств продукции или уменьшение её количества при сохранении наиболее характерных, но несуществующих для её использования свойств [Быковская, Заикина, 2020]. Согласно закону от 02.01.2000 N 29-Ф3 (ред. от 13.07.2020) «О качестве и безопасности пищевых продуктов» [О качестве и безопасности пищевых продуктов], любой продукт, изготовленный не по ГОСТу, состав которого не полностью представлен в документации, может признаваться фальсифицированным.

Проанализировав работы авторов [Мамаев, Понаморева, 2017; Тригуб, Николенко, 2020; Андрейчикова, 2017; Сложенкина и др.,2020; Доценко и др., 2018; Малых, Полиектова, 2017; Конькава, Кошлякова, 2018; Сырых, 2018; Тюкалов,2019; Лютых,2021], мы систематизировали наиболее частые способы фальсификации молока и молочной продукции (рис. 1).

Потребители стараются находить методы определения фальсификации в домашних условиях. Однако недобросовестные производители научились изменять технологию таким образом, чтобы домашние методы определения давали ложноположительные результаты.

Одним из ярких примеров служит метод определения крахмала в молочных продуктах. При добавлении йода крахмал синеет или краснеет. Однако стоит применить не обычный, а модифицированный крахмал - и тест не сработает. 


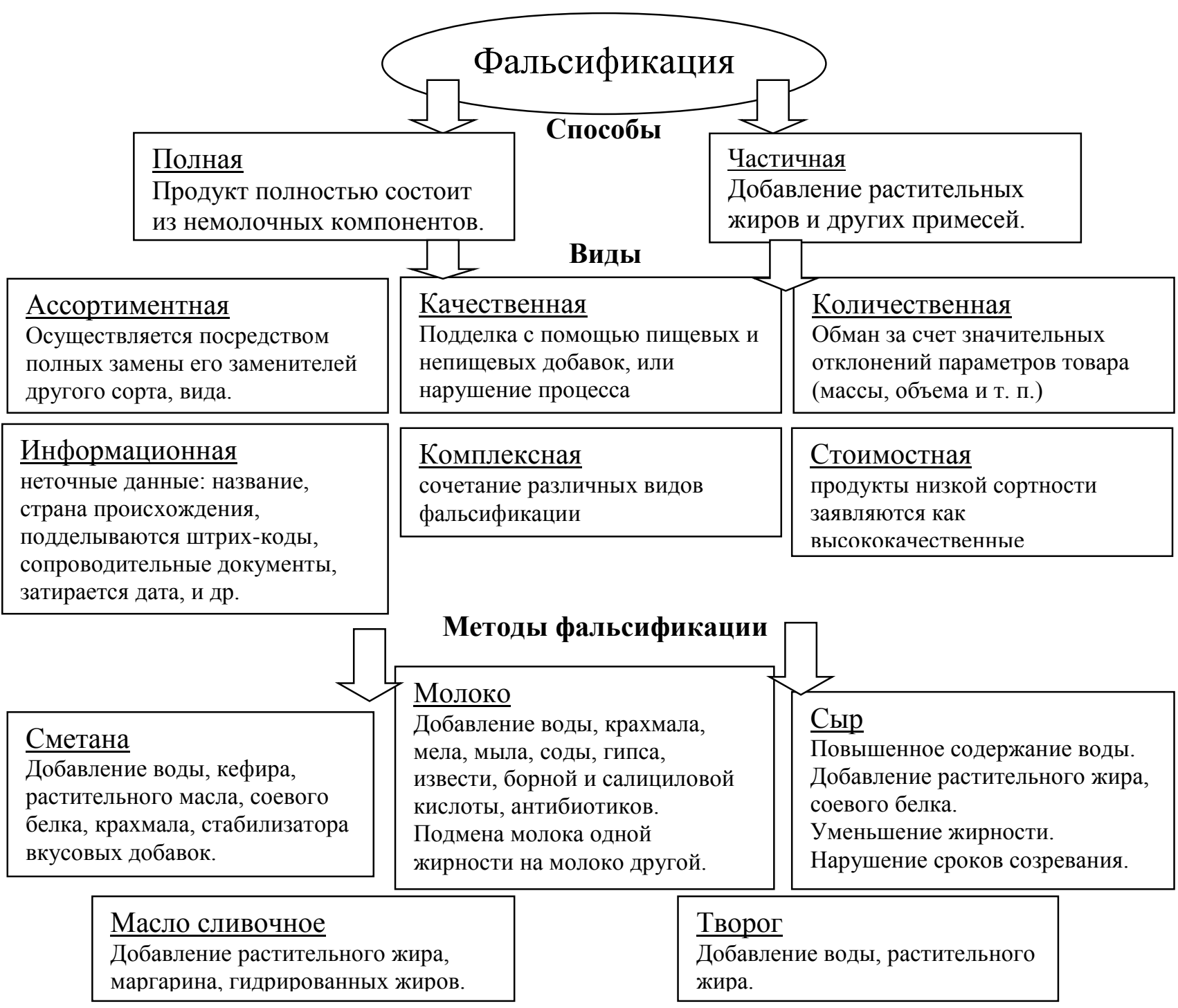

Рис. 1. Систематизация способов, видов и методов фальсификации молока и молочной продукции

Fig. 1. Systematization of methods, types and methods of falsification of milk and dairy products

Формирование цен на молочную продукцию происходит многоступенчато. Именно это создает благоприятные возможности для фальсификации продукции и неправомерного рыночного вмешательства. Фальсификация молочной продукции оказывает влияние на каждый субъект рынка. Так, у покупателей снижается доверие к производителю, что влечет за собой снижение потребительской активности и производители начинают терять прибыль. С рынка вытесняется качественная продукция, добросовестные товаропроизводители с трудом могут конкурировать с недобросовестными и теряют стимул продолжать свою деятельность, процветает мошенничество, государство теряет налоговые отчисления в бюджет, государственные субсидии не дают прогнозируемого результата, что в итоге ведет к подрыву экономической безопасности страны (рис. 2).

В существенной степени на фальсификацию молочной продукции влияние оказывают низкие доходы населения. Ассортимент бюджетных аналогов с добавлением растительного жира значительно шире, а дешевые молочные продукты более востребованы покупателями, испытывающими финансовые трудности. Как отмечает Алексеенкова Е. [Койнова, 2019], порядка 20 млн россиян живут за чертой бедности. И даже если потребители понимают, что они приобретают ненатуральный продукт, располагаемые средства вынуждают их покупать фальсификат, в котором, в лучшем случае, сохранена белковая составляющая, а молочный жир заменён на значительно более дешёвый растительный. Государство же, вместо 
стимулирования роста реальных доходов населения, снижения цен на молочные продукты за счет увеличения их производства и уровня конкуренции, развития социальных программ, способствующих потреблению натуральных молочных продуктов, по сути поощряет недобросовестную конкуренцию, производство фальсифицированной молочной продукции и суррогатов.

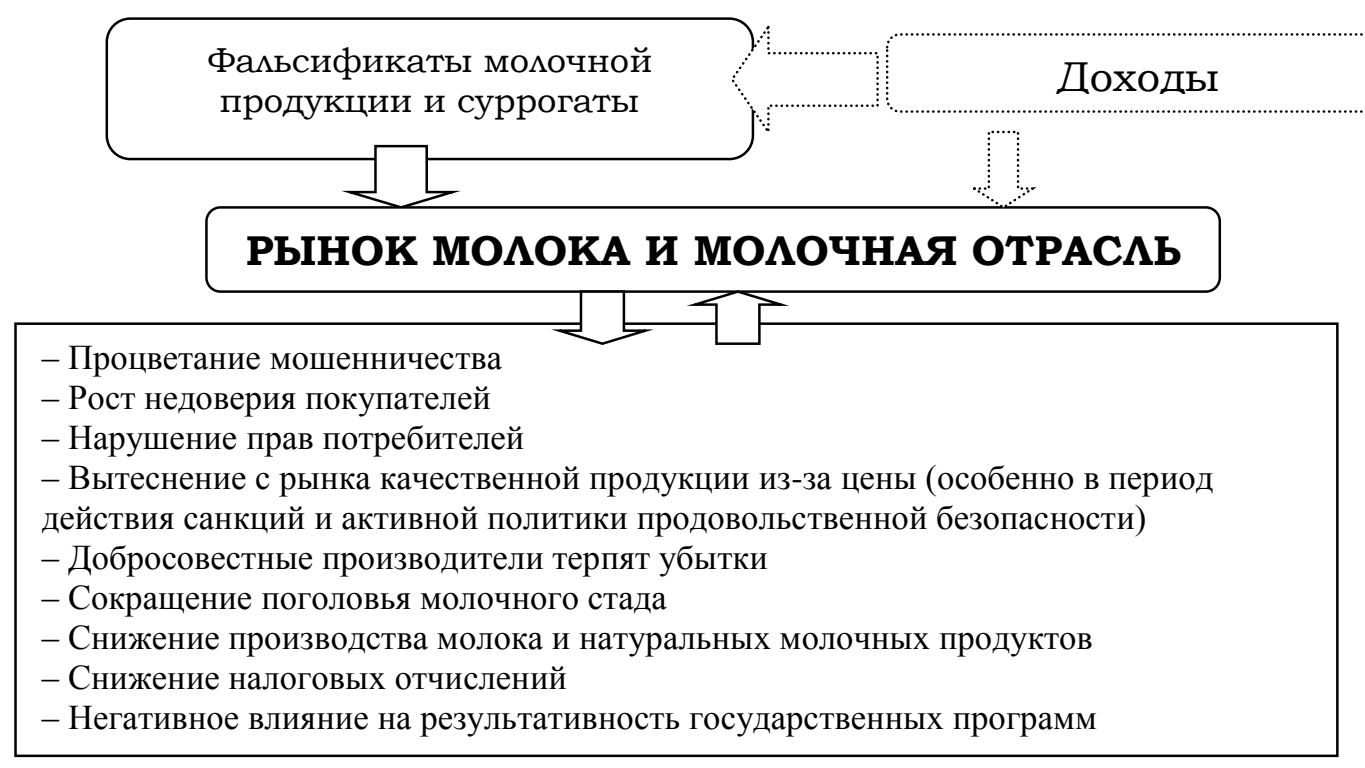

Рис. 2. Влияние фальсифицированной молочной продукции и суррогатов на рынок молока и состояние молочной отрасли

Fig. 2. The impact of falsified dairy products and surrogates on the milk market and the state of the dairy industry

В некоторой степени способствует развитию рассматриваемой проблемы незнание и непонимание покупателями характеристик продукта. Потребитель только после покупки и вскрытия упаковки может оценить продукт, но как говорилось выше, даже существующие бытовые методы не в полной мере позволяют определить натуральность молока и продуктов его переработки. Авторы статьи [Сложенкина и др., 2020] отмечают особенности маркировки молочных продуктов. Они направлены на визуальное разделение натуральных молочных продуктов от продуктов с заменителями молочного жира. С этой целью введены аббревиатуры «СЗМЖ» и «БЗМЖ», соответственно содержащие заменитель молочного жира и без содержания заменителя молочного жира. Таким образом, законодатель фактически перекладывает ответственность за потребление трансжиров на самого потребителя, не запрещая использование данных ингредиентов в производстве молочных продуктов, а только обязывая производителя указывать их наличие на упаковке.

Используя модель пяти конкурентных сил Майкла Портера, мы попытались оценить угрозы фальсификатов и суррогатов на рынок молока и молочной продукции. Данные проведенного анализа представлены в таблице 1.

Чем привлекательнее цена товаров-заменителей, тем прочнее их позиции на рынке. Товары-заменители (в нашем случае фальсифицированные товары) ограничивают потенциал роста цен на рынке. Участники рынка должны не только повышать качество продукции, но и дифференцировать свой товар от товаров-заменителей. Иначе они будут иметь невысокую прибыль и терять покупателей.

Затраты для входа в отрасль высокие, что должно усложнять для новых конкурентов появление на рынке. Однако недобросовестные товаропроизводители могут уменьшать влияние порога вхождения за счет фальсификации продукции (т. е. уменьшения затрат при производстве). 
Анализ конкуренции на рынке молока и молочной продукции по модели М. Портера

Analysis of competition in the market of milk and dairy products according to the model of M. Porter

\begin{tabular}{|c|c|c|}
\hline Параметр & Значение & Описание \\
\hline $\begin{array}{l}\text { Угроза со стороны } \\
\text { товаров-заменителей }\end{array}$ & Высокий уровень & $\begin{array}{l}\text { Tовар не уникальный, существует значительное } \\
\text { количество аналогов, в том числе и сомнительного } \\
\text { качества }\end{array}$ \\
\hline $\begin{array}{l}\text { Угрозы } \\
\text { внутриотраслевой } \\
\text { конкуренции }\end{array}$ & Высокий уровень & 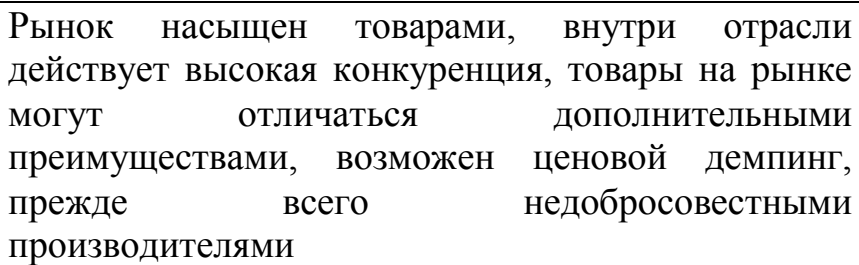 \\
\hline $\begin{array}{l}\text { Угроза входа новых } \\
\text { конкурентов }\end{array}$ & Средний уровень & $\begin{array}{l}\text { 2-3 крупные компании, которые бы держали от } 50 \\
\text { \% рынка, отсутствуют. Инвестиции и затраты для } \\
\text { входа в отрасль высокие. Отрасль развивается. } \\
\text { Открыт доступ к каналам распределения. }\end{array}$ \\
\hline $\begin{array}{l}\text { Угроза рыночной } \\
\text { власти покупателей }\end{array}$ & Высокий уровень & $\begin{array}{l}\text { Объем продаж равномерно распределен между } \\
\text { всеми покупателями. Существование менее } \\
\text { качественных, но экономичных предложений. }\end{array}$ \\
\hline $\begin{array}{l}\text { Угрозы со стороны } \\
\text { поставщиков }\end{array}$ & Низкий уровень & $\begin{array}{l}\text { Широкий выбор поставщиков, низкие издержки } \\
\text { при смене поставщика, высокая приоритетность } \\
\text { отрасли для поставщиков. }\end{array}$ \\
\hline
\end{tabular}

Покупатели также оказывают влияние, отдавая предпочтение более дешевым, но менее качественным товарам. Таким образом, потребители могут «вытеснить» качественную продукцию более дешевым, но некачественными аналогами. Так как отрасль для поставщиков привлекательна, они заинтересованы в реализации продукции, пусть и фальсифицированной. Таким образом, фальсификаты подрывают рынок, нарушают установленные связи между продавцами и покупателями, заполняют прилавки некачественной, а в худшем случае вредной для здоровья продукцией.

Мониторинг информации показал различные данные о доле фальсификации молока и молочной продукции. Информация труднодоступная, не систематизирована и противоречива. Так, в 2020 году долю фальсификации молока и молочной продукции государственные органы оценивают следующим образом: Роспотребнадзор - $6 \%$, Роскачество - $1 \%$, Россельхознадзор - 17 \% [Россельхознадзор видит значительное снижение доли фальсификата на продовольственном рынке; Доля фальсификата молочной продукции в России составляет $6 \%$ - Роспотребнадзор; Роскачество: 1 \% молочной продукции в России фальсификат]. Альтернативные же негосударственные источники называют 30-50-70 \%.

Ввиду значительных разночтений по данной проблеме для более объективной оценки уровня фальсификации молочной продукции нами предложен методический подход, в основе которого лежит сравнение производства товарного сырого молока в РФ и продуктов его переработки, исходя из данных официальной статистики и примерных норм расхода молока-сырья на единицу готовой продукции.

Как показывают наши расчеты, ежегодно в России производится молочных продуктов значительно больше, чем имеется молочного сырья для их производства. Дефицит молока за анализируемое пятилетие составлял от 10,2 млн тонн в 2016 г. до 8,5 млн тонн в 2020 г. Можно предположить, что разница обеспечивается за счет использования растительных жиров и других компонентов, заменяющих натуральное сырье. В 2019-2020 гг. наблюдается 
сокращение дефицита молока, несмотря на рост производства молочной продукции с $33-$ 34 \% до 25,8 \%. На наш взгляд, эти цифры показывают примерный уровень фальсификации молочной продукции. Россельхознадзор [В России доля фальсификата молочной продукции снизилась до 17 \%.] также публикует данные о постепенном снижении доли фальсификации молока и молочной продукции: в 2018 году - 21,6 \%, в $2019-19 \%$, в 2020 - $17 \%$.

Таблица 2

Table2

Производство молока и молочной продукции в России, тыс. т

Production of milk and dairy products in Russia, thousand tons

\begin{tabular}{|c|c|c|c|c|c|}
\hline $\begin{array}{c}\text { Наименование } \\
\text { продукции }\end{array}$ & 2016 год & 2017 год & 2018 год & 2019 год & 2020 год \\
\hline $\begin{array}{l}\text { Молоко } \\
\text { пастеризованное }\end{array}$ & 4993,9 & 4875,9 & 5581,7 & 5370,5 & 5417,2 \\
\hline Масло сливочное & 229,4 & 246,7 & 256,5 & 257,0 & 282,0 \\
\hline Сыры & 402,8 & 423,6 & 474,0 & 521,3 & 566,1 \\
\hline Творог & 404,5 & 490,6 & 495,6 & 462,1 & 492 \\
\hline Сметана & 585,8 & 569,5 & 540,2 & 511,7 & 518,4 \\
\hline Кефир & 1068,1 & 1033,9 & 1021,8 & 968,5 & 886,5 \\
\hline Йогурт & 778,8 & 790,8 & 783,5 & 827,4 & 808,1 \\
\hline Мороженое & 407,1 & 376,9 & 438,6 & 410,3 & 314,4 \\
\hline Сгущенное молоко & 472,0 & 478,1 & 246,6 & 299,2 & 228,0 \\
\hline $\begin{array}{cc}\text { Нормативный } & \text { расход } \\
\text { молочного сырья } & \end{array}$ & 30500 & 31500 & 32500 & 32300 & 33000 \\
\hline $\begin{array}{l}\text { Фактический объем } \\
\text { молока, реализованного в } \\
\text { переработку }\end{array}$ & 20300 & 21005 & 21493 & 22450 & 24470 \\
\hline Дефицит молока & 10200 & 10495 & 11007 & 9850 & 8530 \\
\hline То же в процентах & 33,4 & 33,3 & 33,9 & 30,5 & 25,8 \\
\hline $\begin{array}{l}\text { Дополнительное } \\
\text { поголовье коров, тыс. } \\
\text { гол. }\end{array}$ & 2418,2 & 2402,7 & 1851,5 & 1422,6 & 1241,2 \\
\hline
\end{tabular}

В результате фальсификации молочных продуктов наиболее сильно страдает молочная отрасль сельского хозяйства. Поголовье молочного стада при сложившемся уровне молочной продуктивности недосчитывало ежегодно от 2 млн голов в 2016 г. до 1,2 млн голов в 2020 г. В результате повсеместно можно наблюдать заброшенные фермы, ежегодное сокращение поголовья коров, сельскую безработицу.

Государство принимает некоторые меры для снижения уровня фальсификации молочной продукции и оздоровления рынка. В 2018 г. была запущена система ветеринарной сертификации «Меркурий». С помощью электронной документации данной системы можно проследить весь путь продукта от производства сырья до момента реализации товара животного происхождения. Все звенья производственной цепочки теперь прозрачны, пройти электронную ветеринарную сертификацию обязаны все компании, участвующие в обороте товаров, вплоть до розничных торговых точек и объектов общественного питания. По мнению специалистов [Ситников, 2019; Лютых, 2021; Алексеенкова, 2020; Койнова, 2019; Хасанова, 2019], система ФГИС «Меркурий» положительно себя зарекомендовала. Распространение системы осуществлялось в 2 этапа: 1 этап с 1 июля 2019 г.: сыр, сливочное масло и сгущенное молоко; 2 этап с 1 ноября 2019 г.: кефир, йогурт, молоко в потребительской упаковке, мороженое и другие молочные продукты.

Между тем недостаток данной системы заключается в том, что право оформления ветеринарных сопроводительных документов имеют уполномоченные лица предприятий, у которых есть большой соблазн и возможность фальсифицировать ветеринарные 
сопроводительные документы. Существует и ряд других проблем. Проверки продукции должны носить системный характер в течение года. А их результаты должны быть доступны и систематизированы.

\section{Заключение}

Для устранения фактов фальсификации продукции стоит действовать по нескольким направлениям.

1. Стимулирование привлечения инвестиций в молочное скотоводство для создания как крупных, высокотехнологичных предприятий, так и средних с использованием современных технологий содержания и кормления стада, что должно способствовать удешевлению молочного сырья.

2. Продолжать политику государственной поддержки сельского хозяйства, в частности, по молочному направлению.

3. На законодательном уровне запретить использование заменителей, растительных жиров в молоке и молочной продукции. За нарушение назначить штрафы в кратном размере от суммы выручки с продаж фальсифицированной продукции.

4. Запустить электронное приложение с перечнем недобросовестных производителей. А также установить на торговых площадях устройства, предоставляющие покупателю информацию о производителе. Достаточно занести название, чтобы на табло выходила вся основная информация, в том числе и о проверке на качество продукции.

5. Разместить стенды на торговых площадях, где четко объяснена разница между продуктами.

Проблема фальсификации продукции оказывает влияние не только на рынок и экономику молочной отрасли, но и на здоровье граждан: отравления различной степени тяжести, аллергические реакции, длительное воздействие повышенных содержаний тяжелых металлов в пищевых добавках, развитие сердечно-сосудистых, онкологических и других заболеваний, результаты деятельности недобросовестных производителей. Что только повышает важность решения данной проблемы.

\section{Список источников}

1. В России доля фальсификата молочной продукции снизилась до $17 \%$. URL: https://agrobook.ru/news/61335/v-rossii-dolya-falsifikata-molochnoy-produkcii-snizilas-do-17 (дата обращения 01.06.2021).

2. Доля фальсификата молочной продукции в России составляет $6 \%$ - Роспотребнадзор URL: https://www.dairynews.ru/news/dolya-falsifikata-molochnoy-produktsii-v-rossii-so.html?type=mobile (дата обращения 01.06.2021).

3. Министерство сельского хозяйства Российской Федерации URL:https://mcx.gov.ru/ (дата обращения 24.05.2021).

4. Роскачество: $1 \%$ молочной продукции в России - фальсификат Seldon.News. URL:https://news.myseldon.com/ru/news/index/251708936(дата обращения 0.06.2021).

5. Россельхознадзор видит значительное снижение доли фальсификата на продовольственном рынке. URL: https://milknews.ru/index/rskhn-snizhenie-falsifikata.html (дата обращения 01.06.2021).

6. Управление Федеральной службы по надзору в сфере защиты прав потребителей и благополучия человека по республики Алтай. URL:http://04.rospotrebnadzor.ru/index.php/sannadzor/43-san-ottel/1234-22082011.html (дата обращения 22.05.2021).

7. Федеральный закон от 02.01.2000 N 29-Ф3 (ред. от 13.07.2020) «О качестве и безопасности пищевых продуктов». Начало действия редакции - 28.08.2020: справочно-правовая система «КонсультантПлюс».

\section{Список литературы}

1. Алексеенкова Е. 2020. Правда о молоке. Пищевая индустрия, 1 (43): 13-15.

2. Андрейчикова А.А. 2017. Проблемы фальсификации молока и молочной продукции. 
Евразийское пространство: добрососедство и стратегическое партнерство: материалы VIII Евразийского экономического форума молодежи. Екатеринбург: Уральский государственный экономический университет, том 3: 131-133.

3. Быковская Е.И., Заикина М.А. 2020. Актуальные вопросы фальсификации молочной продукции и меры ее предотвращения. Новые концептуальные подходы к решению глобальной проблемы обеспечения продовольственной безопасности в современных условиях: материалы VII международной научно-практической конференции. Курск : Юго-Западный государственный университет: 90-94.

4. Доценко Е.Н., Заболотных М.В., Таганова Т.В. 2018. Способы фальсификации молочной продукции. Достижения науки и образования, 12(34): 68-69.

5. Койнова А.Н. 2019. На страже интересов молочной промышленности. Пищевая индустрия, 3 (41): $22-24$.

6. Конькова Ю.С., Кошлякова И.Г. 2018. Методы измерений при обеспечении качества и безопасности молочной продукции. Прогрессивные технологии и процессы: материалы 5-й Всероссийской научно-технической конференции с международным участием. Курск: Закрытое акционерное общество «Университетская книга»: 143-146.

7. Лютых О. 2021. Нормативная база молочной промышленности - залог успешного развития отрасли. Пищевая индустрия, 1 (45): 52-54.

8. Малых М.А., Полиектова Е.Л. 2017. Проблемы идентификации молочной продукции и пути их решения. Контроль качества продукции, 2: 6-9.

9. Мамаев Е.А., Понаморева Е.Д. 2017. Актуальные вопросы фальсификации молочной продукции. Зеленый коридор, 2: 116-119.

10.Руднева А.И., Воробей М.А. 2019. Проблемы идентификации и фальсификации молочной продукции. Моя профессиональная карьера, 1 (5): 40-49.

11.Ситников Д.Д. 2019. Фальсификация товаров и методы борьбы с ней . Экономическая безопасность: проблемы, перспективы, тенденции развития: материалы V Международной научнопрактической конференции. Пермь: Пермский государственный национальный исследовательский университет: 861-865.

12.Сложенкина М.И., Матвеева Л.В., Федотова А.М., Мосолова Е.А. 2020. Проблемы фальсификации молочной продукции. Аграрно-пищевые инновации, 1(9): 66-73.

13.Сырых Т.Е. 2018. К вопросу о причинах фальсификации молочной продукции и способах ее выявления. Международный студенческий научный вестник, 6: 82.

14.Тригуб В.В., Николенко М.В. 2020. Изучение качества и безопасности молочных продуктов. Ползуновский вестник, 3: 44-47.

15.Тюкалов Д.В. 2019. Фальсификация товаров как угроза экономической безопасности Российской Федерации. Экономическая безопасность: проблемы, перспективы, тенденции развития: материалы $\mathrm{V}$ международной научно-практической конференции. Пермь: Пермский государственный национальный исследовательский университет: 934-941.

16.Хасанова, В.Е. 2019. Достоинства и недостатки внедрения федеральной государственной информационной системы «Меркурий». Молодой ученый, 46 (284): 28-31. URL: https://moluch.ru/archive/284/63907/ (дата обращения: 02.07.2021).

\section{References}

1. Alekseenkova E. 2020. Pravda o moloke. [The truth about dairy]. Pishhevaja industrija, 1 (43): $13-15$.

2. Andrejchikova A.A. 2017. Problemy fal'sifikacii moloka i molochnoj produkcii. [Problems of counterfeiting dairy products] Evrazijskoe prostranstvo: dobrososedstvo i strategicheskoe partnerstvo: materialy VIII Evrazijskogo jekonomicheskogo foruma molodezhi. Ekaterinburg :Ural'skij gosudarstvennyj jekonomicheskij universitet, tom 3: 131-133.

3. Bykovskaja E.I., Zaikina M.A. 2020. Aktual'nye voprosy fal'sifikacii molochnoj produkcii i mery ee predotvrashhenija. [Topical issues of counterfeiting of dairy products and measures to prevent it] Novye konceptual'nye podhody $\mathrm{k}$ resheniju global'noj problem obespechenija prodovol'stvennoj bezopasnosti v sovremennyh uslovijah: materialy VII mezhdunarodnoj nauchno-prakticheskojkonferencii. Kursk :Jugo-Zapadnyj gosudarstvenny juniversitet: 90-94.

4. Docenko E.N., Zabolotnyh M.V., Taganova T.V. 2018. Sposoby fal'sifikacii molochnoj produkcii. [Ways of falsifying dairy products]. Dostizhenija nauki i obrazovanija, 12(34): 68-69. 
5. Kojnova A.N. 2019. Na strazhe interesov molochnoj promyshlennosti. [Guarding the interests of dairy products] Pishhevaja industrija, 3 (41): 22-24.

6. Kon'kovaJu.S., Koshljakova I.G. 2018. Metody izmerenij pri obespechenii kachestva i bezopasnosti molochnoj produkcii. [Methods for measuring the quality of dairy products]. Progressivnye tehnologii i processy: materialy 5-j Vserossijskoj nauchno-tehnicheskoj konferencii s mezhdunarodnym uchastiem. Kursk :Zakrytoe akcionernoe obshhestvo "Universitetskaja kniga": 143-146.

7. Ljutyh O. 2021. Normativnaja baza molochnoj promyshlennosti - zalog uspeshnogo razvitija otrasli. [The regulatory framework of the dairy industry is the key to the successful development of the industry]. Pishhevaja industrija, 1 (45): 52-54.

8. Malyh M.A., Poliektova E.L. 2017. Problemy identifikacii molochnoj produkcii i puti ih reshenija. [Problems of identification of dairy products and ways to solve them]. Kontrol' kachestva produkcii, 2: 6-9.

9. Mamaev E.A., Ponamoreva E.D. 2017. Aktual'nye voprosy fal'sifikacii molochnoj produkcii. [Topical issues of falsification of dairy products]. Zelenyj koridor, 2: 116-119.

10.Rudneva A.I., Vorobej M.A. 2019. Problemy identifikacii i fal'sifi-kacii molochnoj produkcii. [Problems of identification and falsification of dairy products]. Moja professional'naja kar'era, T. 1. № 5: 40-49.

11.Sitnikov D.D. 2019. Fal'sifikacija tovarov i metody bor'by s nej. [Counterfeiting of goods and methods of combating it]. Jeko-nomicheskaja bezopasnost': problemy, perspektivy, tendenciirazvitija: materialy V Mezhdunarodnoj nauchno-prakticheskoj konferencii.-Perm' :Permskij gosudarstvennyj nacional'nyj issledovatel'skij universitet: 861-865.

12.Slozhenkina M.I., Matveeva L.V., Fedotova A.M., Mosolova E.A. 2020. Problemy fal'sifikacii molochnoj produkcii. [Problems of counterfeiting dairy products]. Agrarno-pishhevy einnovacii, 1(9): 66-73.

13.Syryh T.E. 2018. K voprosu o prichinah fal'sifikacii molochnoj produkcii i sposobah ee vyjavlenija. [On the question of the reasons for the falsification of dairy products and how to identify it.] Mezhdunarodnyj studencheskij nauchnyj vestnik, 6: 82.

14.Trigub V.V., Nikolenko M.V. 2020. Izuchenie kachestva i bezopasnosti mo-lochnyh produktov. [Study of the quality and safety of dairy products.] Polzunovskij vestnik, 3: 44-47.

15.Tjukalov D.V. 2019. Fal'sifikacija tovarov kak ugroza jekonomicheskoj bez-opasnosti Rossijskoj Federacii. [Counterfeiting of goods as a threat to the economic security of the Russian Federation]. Jekonomicheskaja bezopasnost': problemy, perspekti-vy, tendenciirazvitija: materialy V mezhdunarodnoj nauchno-prakticheskoj konferencii. Perm' :Permskij gosudarstvennyj nacional'nyj issledovatel'skij universitet: 934-941.

16.Hasanova V.E. 2019. Dostoinstva i nedostatki vnedrenija federal'noj gosudarstvennoj informacionnoj sistemy «Merkurij». [Advantages and disadvantages of the implementation of the federal state information system "Mercury"]. Molodoj uchenyj, 46 (284): 28-31. URL: https://moluch.ru/archive/284/63907/ (accessed 02.07.2021).

Конфликт интересов: о потенциальном конфликте интересов не сообщалось.

Conflict of interest: no potential conflict of interest related to this article was reported.

\section{ИНФОРМАЦИЯ ОБ АВТОРЕ}

Жилинкова $\quad$ Ксения
соискатель кафедры бухгалтерского учета и
финансов $\quad$ Курской
сельскохозяйственной государственной
И.И. Иванова, г. Курск, Россия

\section{INFORMATION ABOUT THE AUTHOR}

Ksenia B. Zhilinkova, Candidate of the Department of Accounting and Finance, Kursk State Agricultural Academy named after I.I. Ivanov, Kursk, Russia 